Journal of Engineering and Applied Sciences 14 (11): 3651-3658, 2019

ISSN: 1816-949X

(C) Medwell Journals, 2019

\title{
Distribution of Land Surface Temperatures from Satellite Images for Al-Hammar Marshes In Iraq
}

\author{
${ }^{1}$ Ashraf S. Abdulla, ${ }^{2}$ Bushra Q. Al-Abudi and ${ }^{2}$ Mohammed S. Mahdi \\ ${ }^{1}$ Department of Astronomy and Space, College of Science, University of Baghdad, Baghdad, Iraq \\ ${ }^{2}$ Department of Computer Science, College of Science, University of Al-Nahrain, Baghdad, Iraq
}

\begin{abstract}
In this study, land surface temperatures for Al-Hammar Marshes in Iraq are estimated for years 1991, 2000, 2015 and 2017 using ENVI 5.1 Software programming for the purpose of knowledge the extent of the change in surface temperature of the marshesland by producing digital maps and classified chromatically to the temperature distribution and by taking advantage of the thermal $\mathrm{b}$ and of the satellite landsat sensors TM, ETM+ and OLI. By comparing four different time periods (1991, 2000, 2015 and 2017), we concluded that the surface temperature of Al-Hammar Marshes continued increase. The results indicated that the study area suffering from a clear increase in temperatures included all classes of marshesland where the average temperature for the year 1991 approximately 41.506 while the average temperature value for the year 2000 increased about 44.69 an increase of 3.19 for the year 1991. The average temperature for the year 2015 was approximately 47.31 an increase of 2.62 for the year 2000 while The average temperature for the year 2017 was approximately 47.85 and an increase of 6.35 in comparison with the year 1991.
\end{abstract}

Key words: Land surface temperatures, landsat satellite images, thermal band Al-Hammar Marshes, marshesland, approximately, digital maps

\section{INTRODUCTION}

Remote sensing is the noncontact recording of information from the ultraviolet, visible, infrared and microwave regions of the electromagnetic spectrum by means of instruments such as cameras, scanners, lasers, linear arrays and area arrays located on platforms such as aircraft or space craft and the analysis of acquired information by means of visual and digital image processing (Jensen, 2009). Image acquired by a scanner that records radiation within the thermal infrared band (3-5 and $8-14 \mu \mathrm{m})$ is used to measure the Land Surface Temperature (LST). Most temperature related studies have used polar orbiting satellite systems because of their high spatial and spectral resolution (Sun and Pinker, 2004). LST is an important factor in many areas of studies such as global climate change, hydrological and agricultural processes and urban land use land cover. Calculating LST from remote sensed images is needed, since, it is an important factor controlling most physical, chemical and biological processes of the Earth Becker and Li (1990). Land Surface Temperature (LST) can be defined as the temperature of the surface which we observe if directly contact or touch it with or skin temperature of the surface of the Earth or it is the temperature emitted by the surface (Latif, 2014). Thermal infrared data in the remote sensing can help us obtain quantitative information of surface temperature. The landsat TM, ETM+ and OLI sensors images can be used to study relation between surface temperature and land cover types using thermal quantitative indicators. Sajad et al. used the Temperature-Emissivity Separation (TES) algorithm for LST retrieving from the TIRS (Thermal Infrared Sensor) data of the Landsat Thematic Mapper (TM). The Root Mean Square Error (RMSE) and coefficient of determination ( $\mathrm{R} 2$ were used for validation of retrieved LST values (Zareie et al., 2016). Suresh et al. (2016) applied single window algorithm methods to calculate the LST from TIRS. The heat energy radiated by the Earth's surface determine factors such as different land use types, vegetation cover and soil in the study area reveals the variation in surface temperature of different surface patterns. Surface temperature variation controls the surface heat and water exchange with the atmosphere resulting climatic change in the region. Though some climatic phenomena play a minor role in temperature variation (Suresh et al., 2016).

\section{MATERIALS AND METHODS}

In this research, we selected Al-Hammar Marshes which is one of the three biggest marshes are located in

Corresponding Author: Mohammed S. Mahdi, Department of Computer and Science, College of Science, University of Al-Nahrain, Baghdad, Iraq 


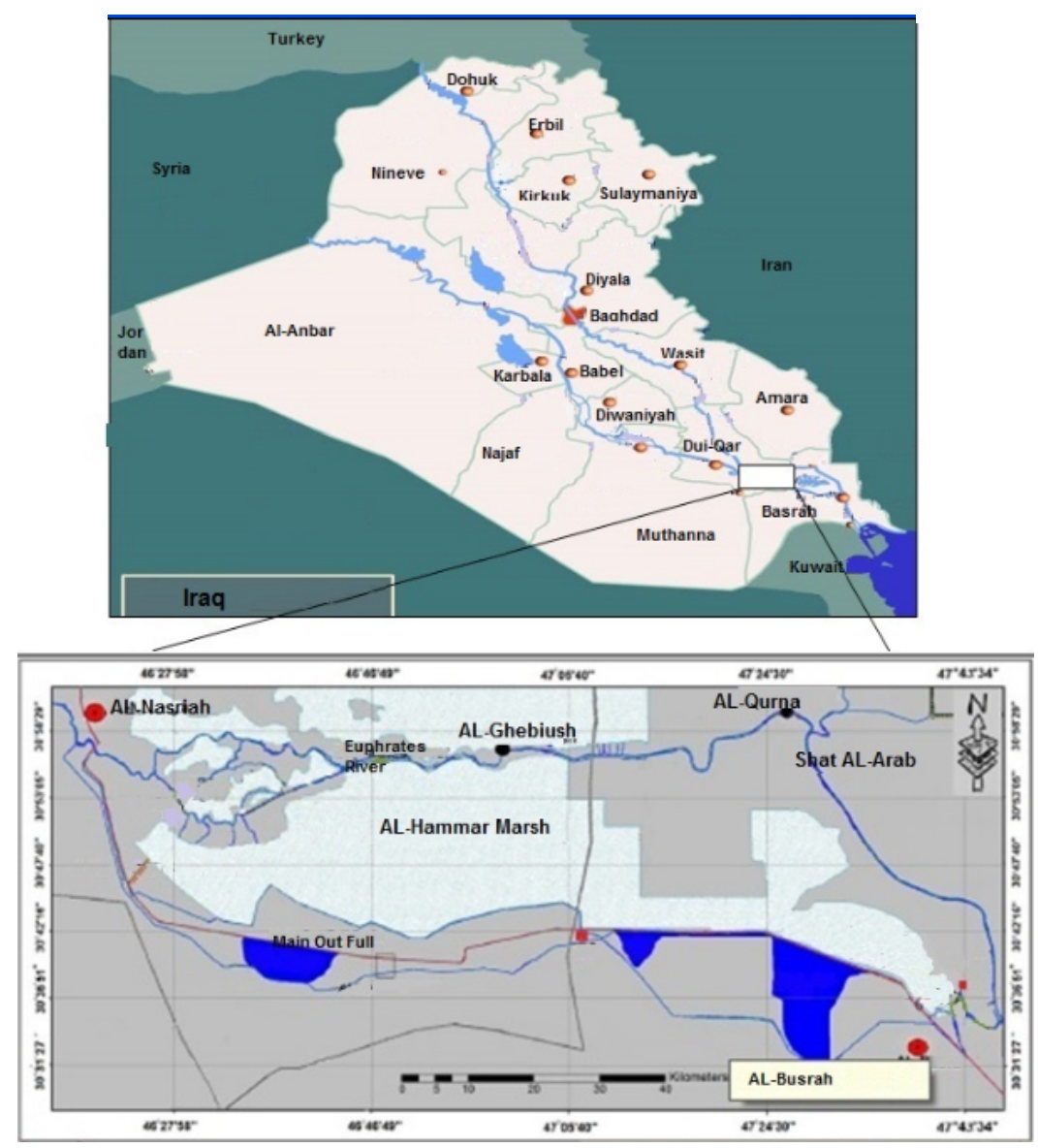

Fig. 1: Location of study area within Iraq

the Southern parts of Iraq is situated to the South of the Euphrates river they are approximately bounded by the following coordinates (longitude $30^{\circ} 45 \mathrm{~s}^{\prime}-30^{\circ} 59^{\prime} \mathrm{N}$, latitude $\left.46^{\circ} 25^{\prime}-4724^{\circ} 15^{\prime} \mathrm{E}^{\prime \prime}\right)$ and has an area ranging from 2800 of contiguous permanent marsh to 4500 during flooding periods (Fig. 1). Four types of satellite image were consulted during the work, Landsat-5 (TM) satellite image (5/6/1991 and 14/6/1991), Landsat-7(ETM+) satellite image $(6 / 6 / 2000$ and $13 / 6 / 2000)$ and Landsat-8 (16/6/2015 and $23 / 6 / 2015)$ and (OLI) satellite image (5/6/2017 and 12/6/2017) with (Path/Row166/39) and (Path/Rowl 67/39). All four images are geometrically projected using Universal Transformed Mercator (UTM) coordinate system and World Geodetic System 1984 (WGS84) zone 38 and obtain from the USGS Earth explorer database.

In this study, land surface temperature of thermal band for Al-Hammar Marshes were estimated using ENVI software programming of thermal bands, generate the temperature color map and analysis their spatial variations using Landsat 7 science data users handbook and Landsat 8 data users handbook procedures. These thermal bands are thermal band $6(10.4-12.5 \mathrm{~nm})$ with $120 \mathrm{~m}$ resolution for year 1991 (Fig. 2), thermal band $6(10.4-12.5 \mathrm{~nm}$ ) with $60 \mathrm{~m}$ resolution for year 2000 (Fig. 3), thermal band $10(10.6-11.19 \mathrm{~nm})$ with $100 \mathrm{~m}$ resolution for year 2015 and 2017 (Fig. 4 and 5). Figure 6 illustrates the block diagram of estimation land surface temperature. Figure 7-10 show thermal band of satellite image after applying mosaic process for year 1991, 2000, 2015 and 2017, respectively. While Fig. 11-14 show thermal band of satellite image after applying clipping process for years 1991, 2000, 2015 and 2017, respectively.

Conversion of thermal digital number value to temperature: The mono window algorithm is based on the premise that the brightness temperature at the satellite level can be retrieved from the thermal band data of landsat, National Aeronautics and Space Administration (NASA) has developed Eq. 1 to compute the spectral radiance from $\mathrm{DN}$ value of landsat data Markham (1986). We import thermal band of satellite images for 4 years which analysis depend to extract the surface temperature as follows: 
(a)

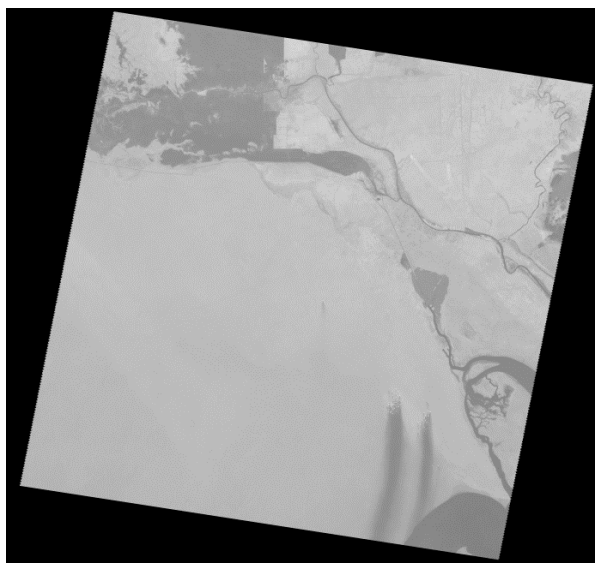

(b)

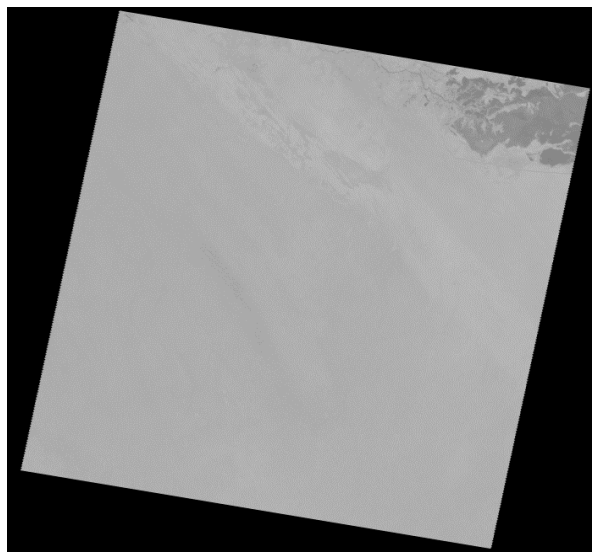

Fig. 2: Landsat satellite image (TM) Thermal band (6) of Al-Hammar Marshes for year 5/6 and 14/6/1991: a) Thermal band row/path 166/39 and b) Thermal band row/path 167/39
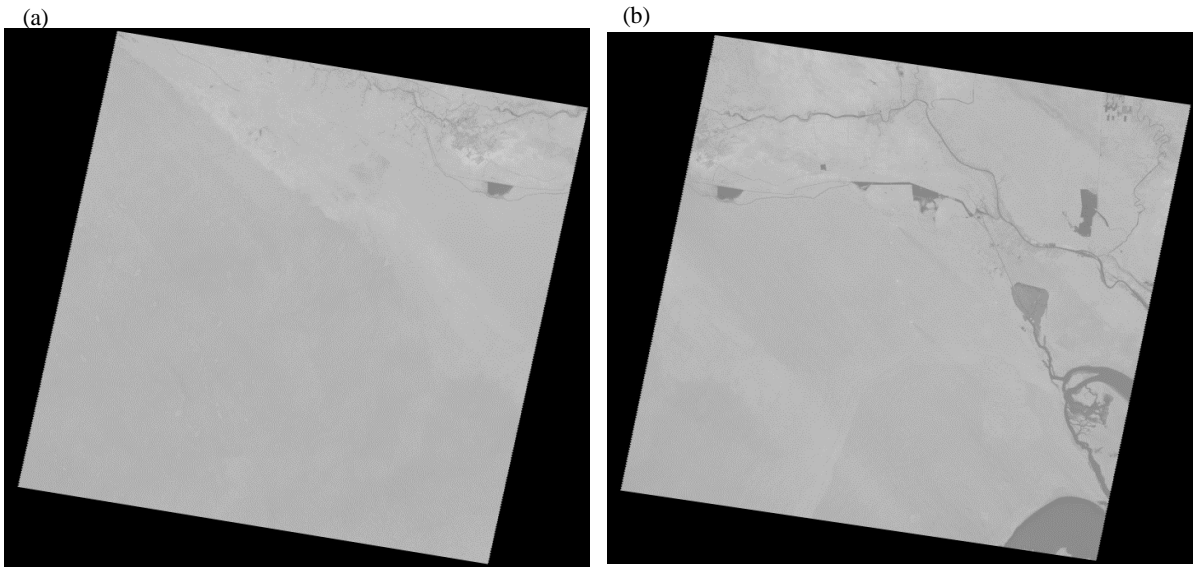

Fig. 3: Landsat satellite image (ETM+) thermal band (6) of Al-Hammar Marshes for year 6/6 and 13/6/2000: a) Thermal band row/path 166/39 and b) Thermal band row/path 167/39
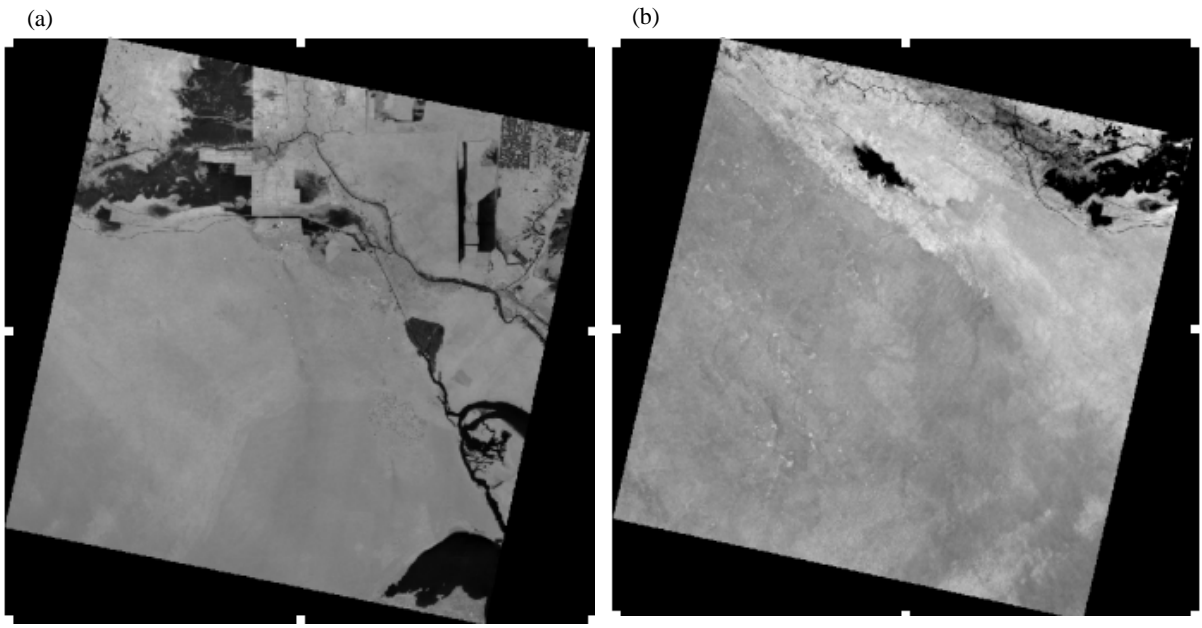

Fig. 4: Landsat satellite image (OLI) thermal band (10) of Al-Hammar Marshes for year 16/6 and 23/6/201 5: a) Thermal band row/path 166/39 and b) Thermal band row/path 167/39 


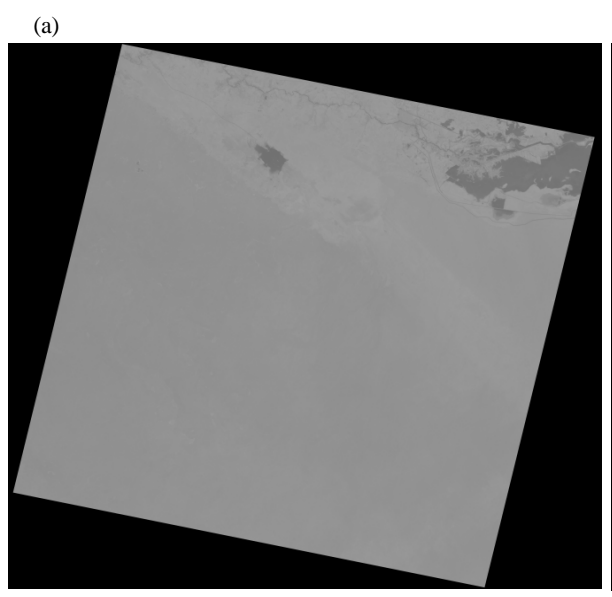

(b)

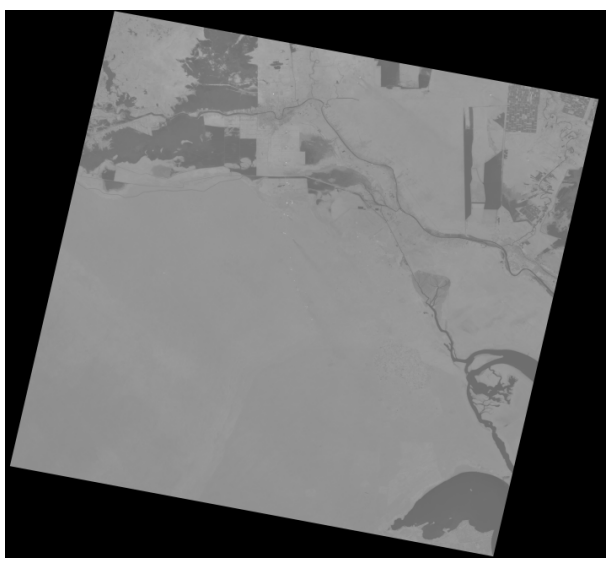

Fig. 5: Landsat satellite image (OLI) thermal band (10) of Al-Hammar Marshes for year 5/6 and 12/6/2017: a) Thermal band row/path 166/39 and b) Thermal band row/path 167/39

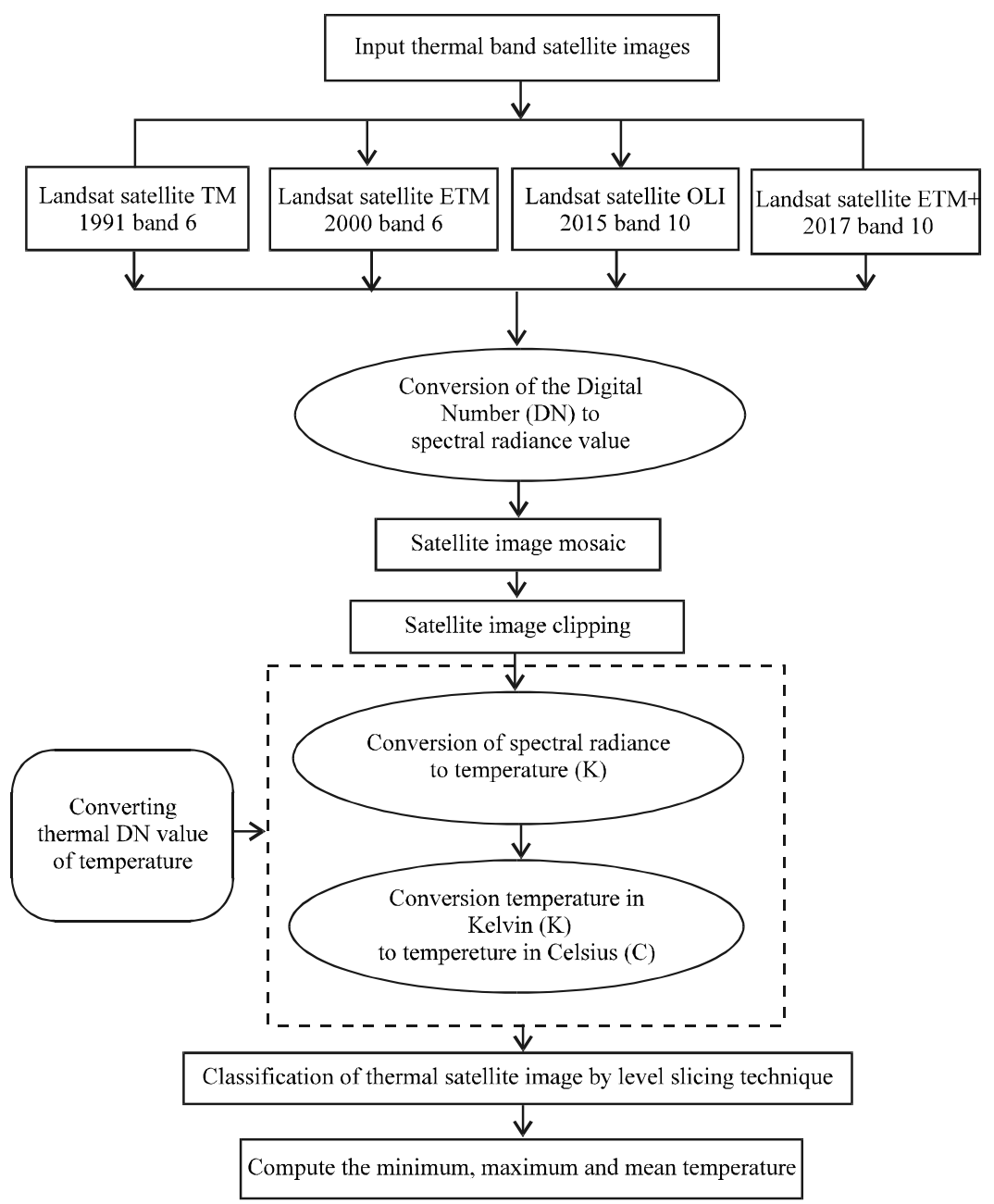

Fig. 6: The block diagram of estimation land surface temperature for thermal bands of satellite image using EVNI programming 


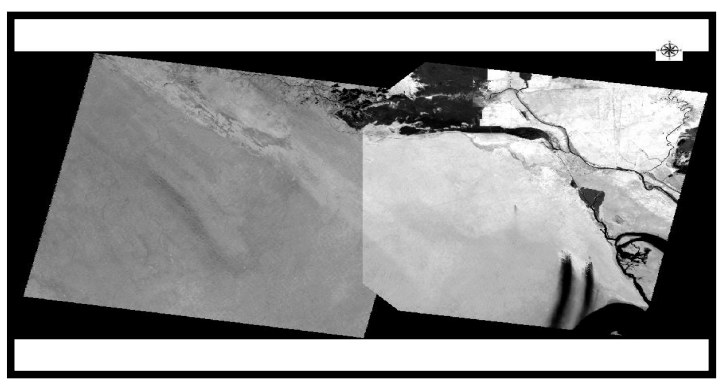

Fig. 7: Mosaic Landsat TM(5/6/1991 and 14/6/1991) band (6) for two satellite images path/row 166/39) and (path/row 167/39)

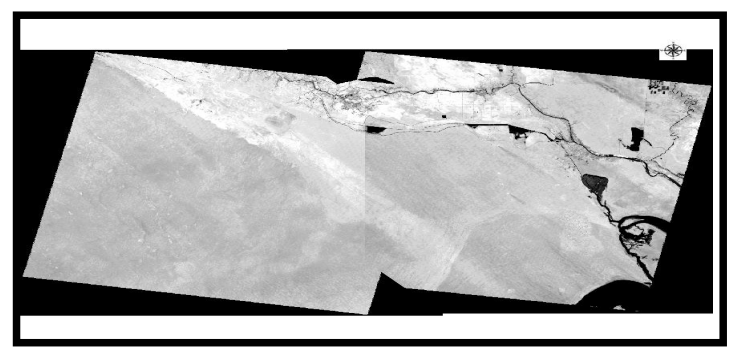

Fig. 8: Mosaic Landsat ETM+(6/6/2000 and 13/6/2000) band (6)for two satellite images (path/row 166/39) and (path/row 167/39)

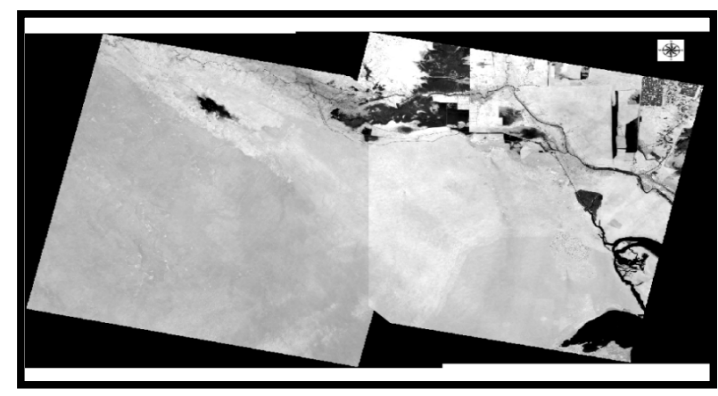

Fig. 9: Mosaic Landsat OLI (16/6/2015 and 23/6/2015) band (10) for two satellite images (path/row 166/39) and (path/row 167/39)

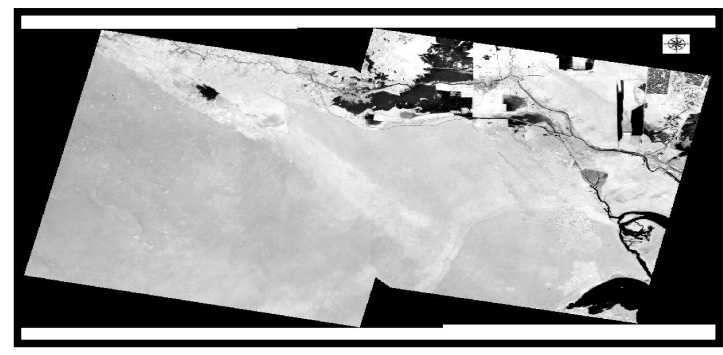

Fig. 10: Mosaic Landsat OLI (5/6/2017 and 12/6/2017) band (10) for two satellite images (path/row 166/39) and (path/row 167/39)

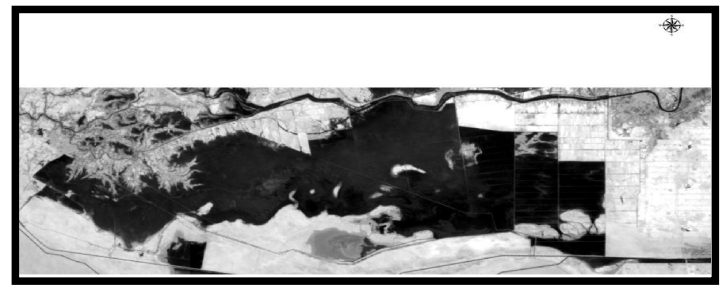

Fig. 11: Landsat-5 (TM) satellite image (band 6), (1991), after applying clipping process

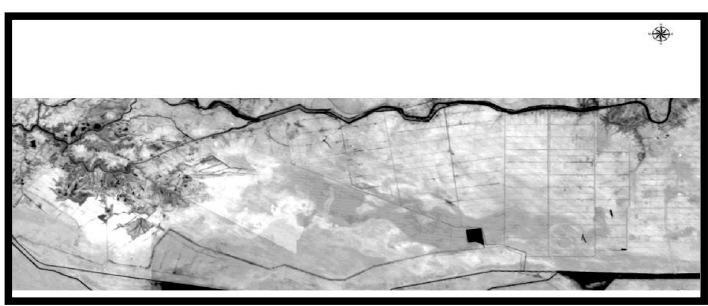

Fig. 12: Landsat-7 (ETM+) satellite image (band 6), (2000) after applying clipping process

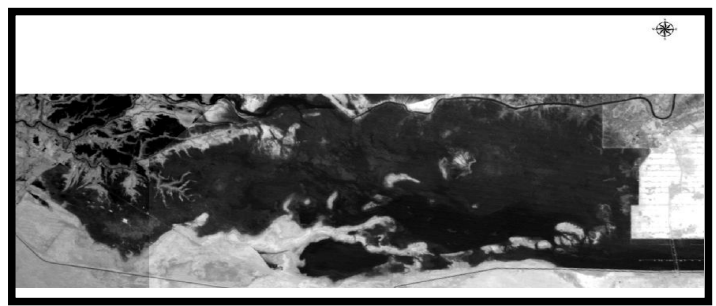

Fig. 13: Landsat-8 (OLI) satellite image) (band 10) (2015, after applying clipping process

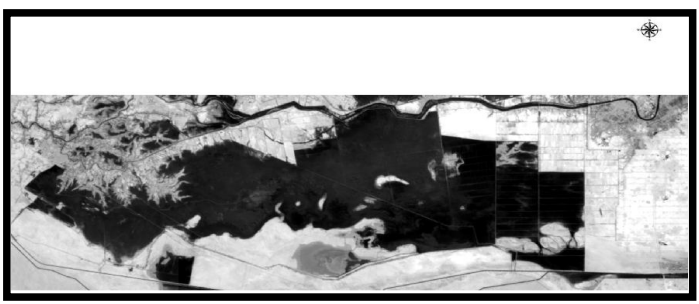

Fig. 14: Landsat-8 (OLI) satellite image (band 10) (2017), after applying clipping process

\section{RESULTS AND DISCUSSION}

Transfer the Digital Number (DN) to spectral radiance: The landsat image storage at Digital Number (DN), DN value has no unit and physical connotation. The DN value range between 0 and 255 initially, we performed Landsat (TM. ETM+ and OLI) calibration to convert DN to radiance/reflectance by using the following Eq. 1: 


$$
\mathrm{L} \lambda=\frac{\left(\mathrm{L}_{\text {max }}-\mathrm{L}_{\text {min }}\right)}{\mathrm{Q}_{\text {cal }-} \mathrm{Q}_{\text {cal min }}} *\left(\mathrm{Q}_{\text {cal }}-\mathrm{Q}_{\text {cal min }}\right)+\mathrm{L}_{\text {min }}
$$

Where:

$$
\begin{aligned}
& \mathrm{L}_{2} \quad=\text { Spectral radiance at the sensor's aperture } \\
& \text { L_and L_ } \quad=\text { The spectral radiances for each band at }
\end{aligned}
$$

Conversion spectral radiance to surface temperature: The spectral radiance was converted to surface temperature by using the following Eq. 2 (Schott and Volchok, 1985):

$$
\mathrm{T}_{\mathrm{Kelvin}}=\frac{\mathrm{K}_{2}}{\ln \left(\frac{\mathrm{K}_{1}}{\mathrm{~L} \lambda}+1\right)}
$$

Where:

$\mathrm{T}=$ The effective Temperature $(\mathrm{K})$

$\mathrm{K}$ and $\mathrm{K} .=$ Calibration constants

The values of these constants can be shown in Table 1 for the thermal band of TM ETM+ and OLI satellite image (NASA, 2010). The spectral radiance can be converted to be brightness temperature of thermal band in Celsius using the following equation (NASA, 2016).

Finally, the output images are classified into different classes using level slicing technique for better understanding of the temperature variation of the marsh land. The thermal pattern distribution of the extracted surface temperature of Al-Hammar Marsh for years 1991,

Table 1: Thermal bands calibration constant of TM ETM+ and OLI

\begin{tabular}{lcr}
\hline Constant & $\left(\mathrm{W} \mathrm{m}^{-2} \mathrm{sr}^{-1} \mu \mathrm{m}^{-1}\right)$ & $\mathrm{K}_{2}(\mathrm{~K})$ \\
\hline Landsat 5-TM & 607.76 & 1260.56 \\
Landsat7-ETM+ & 666.09 & 1282.71 \\
Landsat 8 OLI & 774.89 & 1321.08 \\
\hline
\end{tabular}

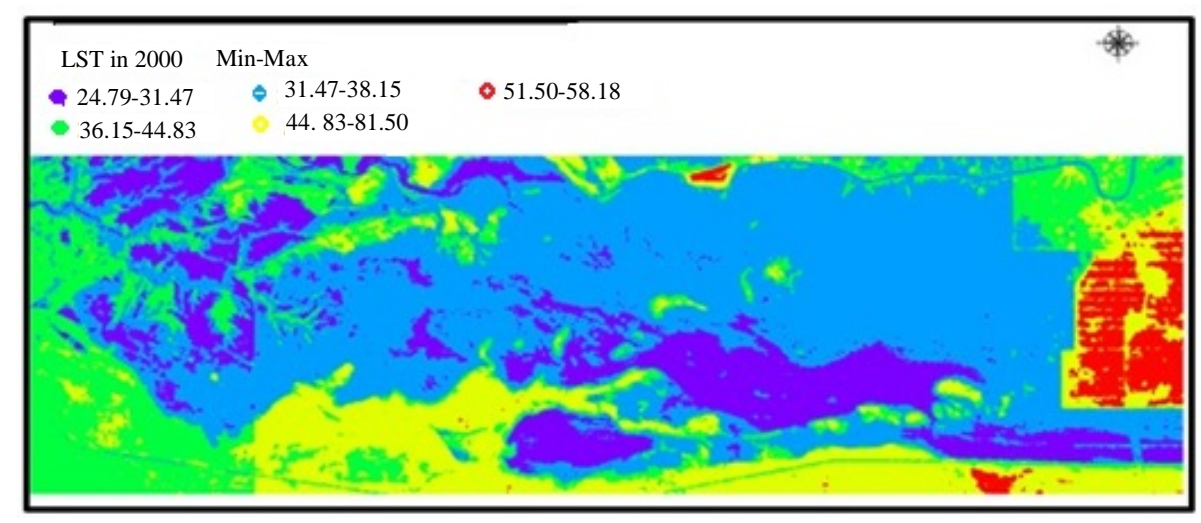

Fig. 15: Thermal distribution map of Al-Hammar Marshes for year $1991\left({ }^{\circ} \mathrm{C}\right)$

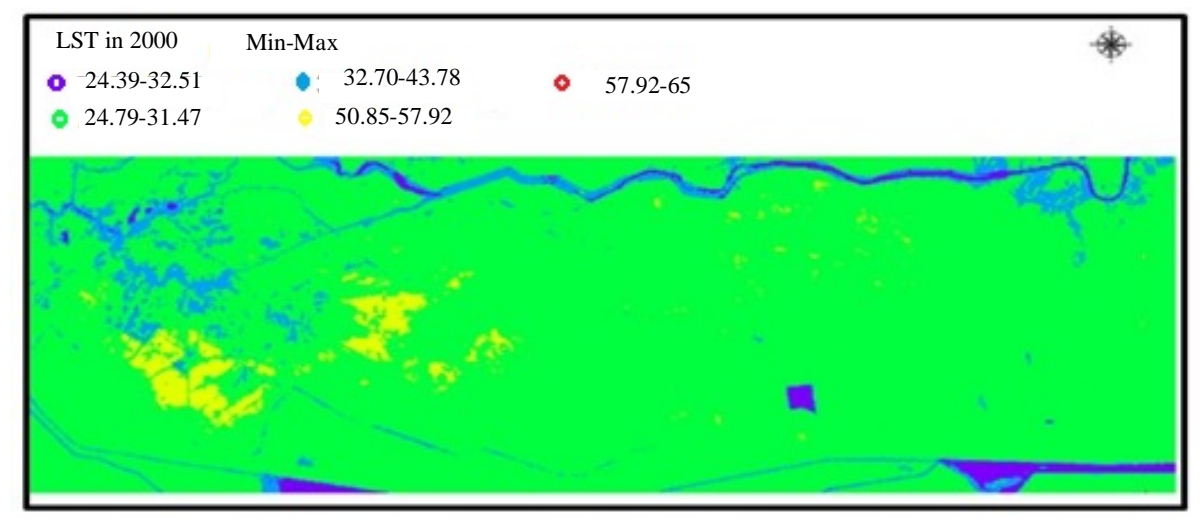

Fig. 16: Thermal distribution map of Al-Hammar Marshes for year $2000\left({ }^{\circ} \mathrm{C}\right)$ 


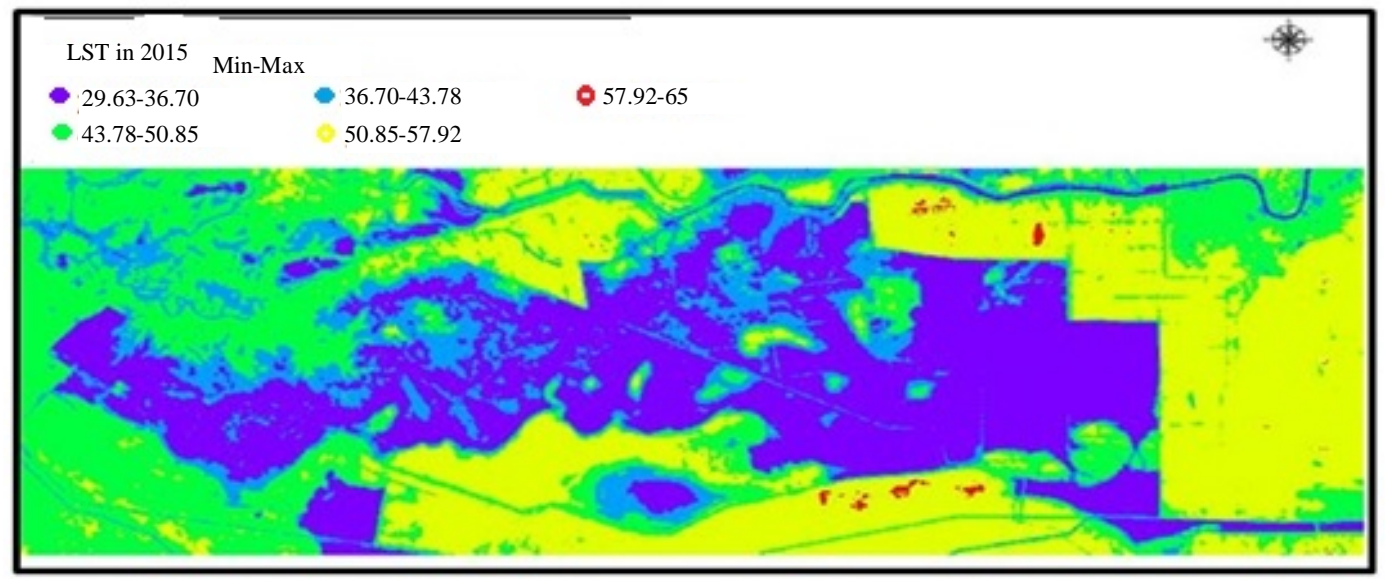

Fig. 17: The thermal distribution map of Al-Hammar Marshes for year $2015\left({ }^{\circ} \mathrm{C}\right)$

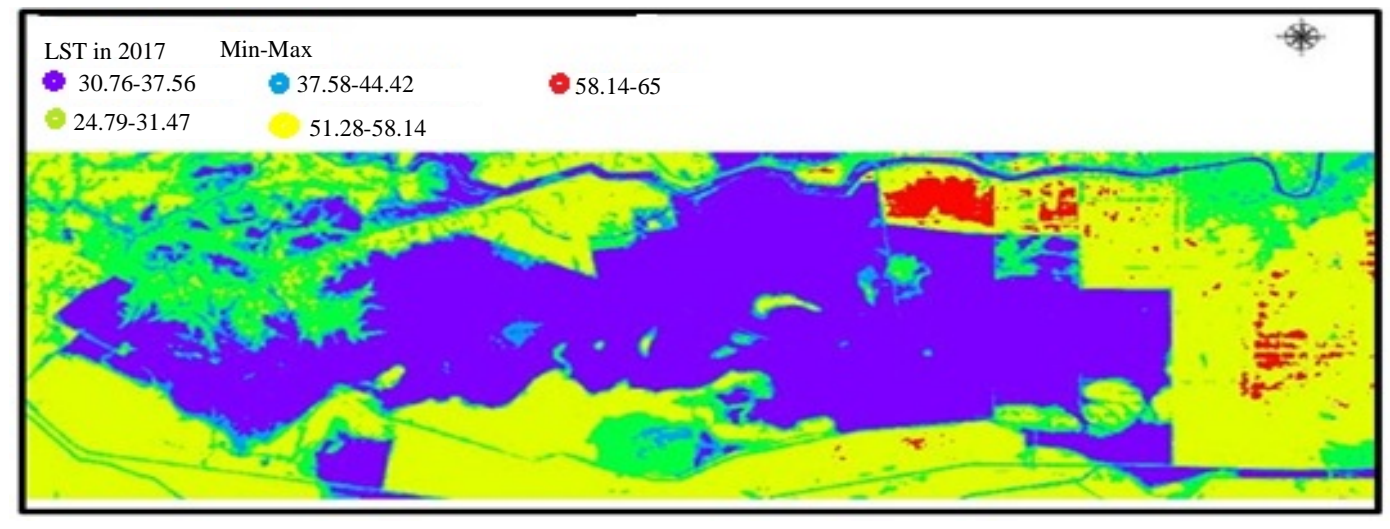

Fig. 18: Thermal distribution map of Al-Hammar Marshes for year $2017\left({ }^{\circ} \mathrm{C}\right)$

Table 2: Statistical significant of Al-Hammar Marshes for year 1991

\begin{tabular}{lccccc}
\hline $\begin{array}{l}\text { Class } \\
\text { color 1991 }\end{array}$ & $\begin{array}{c}\text { Minimum } \\
\text { temp. }\left({ }^{\circ} \mathrm{C}\right)\end{array}$ & $\begin{array}{c}\text { Maximum } \\
\text { temp. }\left({ }^{\circ} \mathrm{C}\right)\end{array}$ & $\begin{array}{c}\text { Average } \\
\text { temp. }\left({ }^{\circ} \mathrm{C}\right)\end{array}$ & SD & $\begin{array}{c}\text { Area } \\
(\%)\end{array}$ \\
\hline Blue & 24.79 & 31.47 & 30.41 & 1.285 & 15.23 \\
Sky blue & 31.47 & 38.15 & 33.51 & 1.576 & 46.38 \\
Green & 30.41 & 44.83 & 42.11 & 1.908 & 19.53 \\
yellow & 1.285 & 51.50 & 47.94 & 1.706 & 15.44 \\
Red & 15.23 & 58.18 & 53.56 & 1.357 & 3.39 \\
Total for classes & - & 7.832 & 99.97 & & \\
Mean temp $\left({ }^{\circ} \mathrm{C}\right)$ & - & 41.506 & - & - & \\
\hline
\end{tabular}

Table 3: Statistical significant of Al-Hammar Marshes for year 2000

\begin{tabular}{|c|c|c|c|c|c|}
\hline $\begin{array}{l}\text { Class } \\
\text { color } 2000\end{array}$ & $\begin{array}{l}\text { Minimum } \\
\text { temp. }\left({ }^{\circ} \mathrm{C}\right)\end{array}$ & $\begin{array}{l}\text { Maximum } \\
\text { temp. }\left({ }^{\circ} \mathrm{C}\right)\end{array}$ & $\begin{array}{l}\text { Average } \\
\text { temp. }\left({ }^{\circ} \mathrm{C}\right)\end{array}$ & $\mathrm{SD}$ & $\begin{array}{c}\text { Area } \\
(\%)\end{array}$ \\
\hline Blue & 24.39 & 32.51 & 28.45 & 2.35 & 1.76 \\
\hline Sky blue & 32.51 & 40.63 & 36.57 & 2.05 & 4.64 \\
\hline Green & 40.63 & 48.75 & 44.69 & 1.71 & 85.91 \\
\hline yellow & 48.75 & 56.87 & 52.81 & 0.96 & 7.67 \\
\hline Red & 56.87 & 65 & 60.93 & 2.08 & 0.002 \\
\hline Total fo & es & 9.15 & 99.98 & & \\
\hline Mean temp. $\left({ }^{\circ} \mathrm{C}\right.$ & C) & 44.69 & - & - & \\
\hline
\end{tabular}

2000, 2015 and 2017 are shown in Fig. 15-18, respectively. Descriptive statistics including minimum, maximum, average and standard deviation of Land Surface
Table 4: Statistical significant of Al-Hammar Marshes for year 2015

\begin{tabular}{lcrcrr}
\hline $\begin{array}{l}\text { Class } \\
\text { color 2015 }\end{array}$ & $\begin{array}{l}\text { Minimum } \\
\text { temp. }\left({ }^{\circ} \mathrm{C}\right)\end{array}$ & $\begin{array}{l}\text { Maximum } \\
\text { temp. }\left({ }^{\circ} \mathrm{C}\right)\end{array}$ & temp. $\left({ }^{\circ} \mathrm{C}\right)$ & $\mathrm{SD}$ & $\begin{array}{c}\text { Area } \\
(\%)\end{array}$ \\
\hline Blue & 29.63 & 36.51 & 33.16 & 1.53 & 27.74 \\
Sky blue & 36.70 & 43.63 & 40.24 & 2.29 & 14.53 \\
Green & 43.78 & 50.85 & 47.31 & 2.03 & 28.32 \\
yellow & 50.85 & 57.92 & 54.38 & 1.65 & 29.17 \\
Red & 57.92 & 65 & 61.46 & 0.64 & 0.21 \\
Total for classes & - & 8.14 & 99.97 & - & - \\
Mean temp $\left({ }^{\circ} \mathrm{C}\right)$ & - & 47.31 & - & - & - \\
\hline
\end{tabular}

Table 5: Statistical significant of Al-Hammar Marshes for year 2017

Class Minimum Maximum Average Area

\begin{tabular}{lllll} 
color $2017 \quad$ temp. $\left({ }^{\circ} \mathrm{C}\right)$ & temp. $\left({ }^{\circ} \mathrm{C}\right)$ temp. $\left({ }^{\circ} \mathrm{C}\right)$ & SD & $(\%)$ \\
\hline
\end{tabular}

\begin{tabular}{llllll}
\hline Blue & 30.70 & 37.56 & 34.13 & 1.46 & 35.49
\end{tabular}

$\begin{array}{llllrr}\text { Sky blue } & 37.56 & 44.42 & 40.99 & 2.13 & 7.12\end{array}$

$\begin{array}{llllll}\text { Green } & 44.42 & 51.28 & 47.85 & 1.9 & 17.47\end{array}$

$\begin{array}{llllll}\text { yellow } & 51.28 & 58.14 & 54.71 & 1.59 & 38.16\end{array}$

$\begin{array}{lrrrrr}\text { Red } & 58.14 & 65 & 61.57 & 0.98 & 1.73\end{array}$

$\begin{array}{llllll}\text { Total for classes } & - & 15.88 & 99.98 & - & \text { - }\end{array}$

\begin{tabular}{|c|c|}
\hline & 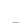 \\
\hline
\end{tabular}

Temperature (LST) of Al-Hammar Marshes for years 1991, 2000,2015 and 2017 are presented in Table 2-5, respectively. 


\section{CONCLUSION}

The temperature variation is derived from TM. ETM+ and OLI sensor thermal bands with the help of Landsat 7 science data users handbook and Landsat 8 data users handbook procedures. Thus, the temperature is estimated for Al-Hammer Marshes satellite images with different spectral resolution for years 1991, 2000, 2015 and 2017. the results indicated that that the area percentage of blue (water) and sky blue (shallow water) represent in year $1991(61.61 \%)$ from the total area and the surface temperature is between $\left(24.79-38.15^{\circ} \mathrm{C}\right)$ in year 2000 was $(6.4 \%)$ from the total area and surface temperature was between $\left(24.39-40.63^{\circ} \mathrm{C}\right)$ in year 2015 was $(42.27 \%)$ from the total area and surface temperature was $\left(29.63-43.78^{\circ} \mathrm{C}\right)$ in year 2017 was $(42.61 \%)$ from the total area and surface temperature was $\left(30.70-44.42^{\circ} \mathrm{C}\right)$. Also, we found that some region have surface temperature more than $65^{\circ} \mathrm{C}$ due to intrusion of mining effect on the nearby area.

\section{ACKNOWLEDGEMENTS}

I would like to express my thanks to my supervisors Professor Dr. Bushra Qassim Al-Abudi who has cheerfully answered my queries, provided me with materials, assisted me in a myriad ways with the writing and helpfully commented on earlier drafts of this research, and Professor Dr. Mohammed Sahib Mahdi Al-Taei for his valuable advice, guidance, constant help and supervision throughout the preparation of this research.

\section{REFERENCES}

Becker, F. and Z.L. Li, 1990. Towards a local split window method over land surfaces. Int. J. Remote Sens., 11: 369-393.
Jensen, J.R., 2009. Remote Sensing of the Environment: An Earth Resource Perspective. 2nd Edn., Pearson Education, London, UK., Pages: 583.

Latif, M.S., 2014. Land surface temperature retrival of landsat- 8 data using split window algorithm-a case study of ranchi district. Intl. J. Eng. Dev. Res., 2: 3840-3849.

Markham, B.L., 1986. Landsat MSS and TM post-calibration dynamic ranges, exoatmospheric reflectances and at-satellite temperatures. Landsat Tech. Notes, 1: 3-8.

NASA., 2010. Landsat-7 Science Data Users Handbook 2010. United States Geological Survey, New York, USA., Page: 186.

NASA., 2016. Landsat-8 Science Data Users Handbook 2016. United States Geological Survey USGS, Sioux Falls, South Dakota, Pages: 106.

Schott, J.R. and W.J. Volchock, 1985. Thematic mapper thermal infrared calibration. Photogrammetric Eng. Remote Sensing, 51: 1351-1357.

Sun, D. and R.T. Pinker, 2004. Case study of soil moisture effect on land surface temperature retrieval. IEEE. Geosci. Remote Sens. Let., 1: 127-130.

Suresh, S., S.V. Ajay and K. Mani, 2016. Estimation of land surface temperature of high range mountain landscape of Devikulam Taluk using Landsat 8 data. Intl. J. Res. Eng. Technol., 5: 92-96.

Zareie, S., H. Khosravi, A. Nasiri and M. Dastorani, 2016. Using landsat Thematic Mapper (TM) sensor to detect change in land surface temperature in relation to land use change in Yazd, Iran. Solid Earth, 7: 1551-1564. 